J. TECHNICAL WRITING AND COMMUNICATION, Vol. 39(4) 381-400, 2009

\title{
VIRTUOUS OR VICIOUS?: AGENCY AND REPRESENTATION IN BIOTECHNOLOGY'S VIRTUOUS CYCLE
}

NAOMI SUNDERLAND

Griffith University, Australia

\begin{abstract}
This article provides a fresh examination of claims that biotechnology and other high profile areas of scientific research and development create a "virtuous cycle" that delivers benefits to society and ecology through an array of consumer products. Specifically, the article investigates who and what has agency in this virtuous cycle and who and what does not. I argue that official discourses on and definitions of biotechnology create strict demarcations not only on who can act in relation to biotechnology research development options, but also on where and at which stages of the virtuous cycle these agents can act. For example, scientists are presented as passive rather than active agents whose influence is limited to the laboratory context despite rhetorical use of their identity and credibility across all contexts of product development and consumption explored. Agency is highly significant in biotechnology and other areas of scientific advance because it determines who or what has moral decision making power regarding the place of new technologies in society. The article concludes with a discussion of the social and ethical impacts of these demarcations of agency in biotechnology's virtuous cycle.
\end{abstract}

In 1999 the Australian National Health and Medical Research Council released a strategic review of Health and Medical Research in Australia titled The Virtuous Cycle: Working together for Health and Medical Research or what is otherwise

(C) 2009, Baywood Publishing Co., Inc.

doi: 10.2190/TW.39.4.c

http://baywood.com 
referred to as "the Wills Review." The authors define "Virtuous Cycle" as "a mutually reinforcing set of actions by the research sector, industry and government" (Commonwealth of Australia, 1999, p. 2). They state that "the outlook of health and medical research lies not only in greater government investment, but also in establishing the links between public funding, research and the commercialisation of findings through industry" (Commonwealth of Australia, 1999). The cycle is presumably "virtuous" because

Commercialisation of research facilitates the delivery of new medicines and treatments to the community. If managed appropriately, it further benefits the community through employment and wealth generation. Minimising barriers between research and industry was a key element of the virtuous cycle outlined in the Review (Commonwealth of Australia, 1999, p. 2).

"The Virtuous Cycle" of medical and health research, as it is presented in the Wills Review, is synonymous with the metaphor of a "product development pipeline" that proliferates in official biotechnology discourses. The notion of a virtuous cycle associated with the product development pipeline adds political emphasis and authority. It is also a positive statement about the social and ethical validity of the prescribed movement and materialization of knowledge in the form of consumer products. Everyone ostensibly benefits from the Virtuous Cycle through the products they consume. The Wills Review authors argued that value is "created" as the new technology or idea moves along the pipeline toward product development, manufacturing, the market, consumption, and ideally profit.

The Wills Review's focus on commercializing publicly funded research for private commercial gain is consistent with developments in the United States two decades ago. The rationale for allowing private companies and universities to take and make life as property and gain from publicly funded research under the Bayh Doyle Act is presented as follows:

Understandably, companies were reluctant to invest in and develop new products if competitors could also acquire licenses and then manufacture and sell the same products. Accordingly, the Government remained unsuccessful in attracting private industry to license government-owned patents. Although taxpayers were supporting the federal research enterprise, they were not benefiting from useful products or the economic development that would have occurred with the manufacture and sale of those products (U.S. Council of Governmental Relations, 1999, np).

The rationale behind the 1980 Bayh Dole Act is, like the Wills Review, that it will deliver hitherto inaccessible benefits of research to taxpayers in the form of products. The ideal is that publicly funded research would "deliver" tangible outcomes to "taxpayers" via the assistance - mediation - of the biopolitical economy: that is, the market is portrayed as the moral medium between research and the community. 
The Virtuous Cycle metaphor has also been used in industry. The following excerpt from the CEO of international data management company Recall provides a good example.

This [virtuous] cycle, in its current form, is benefiting people all over the world. This virtuous cycle of commerce benefits not only the employees who work in specific enterprises, but consumers. It benefits those who the cycle allows to step onto the stair of opportunity, often for the first time. The cycle starts with investment. Investment creates jobs, new opportunities for the people who hold the jobs. These jobs in turn create more demand for goods and services, which itself creates jobs. Many of these jobs, even entry-level jobs, teach skills that lead to better jobs. As more people become more skilled ... opportunity increases for creating more better jobs. Again, Recall is a concrete example of the cycle: While providing a valuable service for our customers, and producing a profit . . . we are also providing new opportunities. This is how the virtuous cycle of commerce works. In our time ... another name for the virtuous cycle of commerce is ... globalization. We all know that "globalization" has vocal critics. They would stop it if they could. But the fact is ... no one ... has developed a formula that benefits people as does the virtuous cycle of commerce. Over the millennia, it has proven to be the best way of enabling more people in more places to escape want and move into a growing circle of prosperity. Globalization is a force for good (Trujillo, 2002, np).

As the above excerpt indicates, the Virtuous Cycle presented in biotechnology policy is an extension of wider politico-economic discourses surrounding product development and sale. Within this broader context, the primary focus of this article is to elucidate who or what is represented as having moral agency in the virtuous cycle of biotechnology. I explore the relationship between agency and social context for the various agents that are presented. A key variable of the analysis is whether or not agents are represented as being active (moral) agents or passive actors who are present in the biotechnology storyline but have little moral authority or decision making power of their own. Agency is important to larger discussions of scientific and technological advance because it shows who gets to evaluate the virtuousness or otherwise of innovation and in which contexts.

\section{THE VIRTUOUS CYCLE IN OFFICIAL BIOTECHNOLOGY DISCOURSE AND POLICY}

The Virtuous Cycle presented in the Wills Review of 2000 was not originally intended to be limited to biotechnological research and development. Official contemporary discourses on biotechnology, on the other hand, were always defined by the virtuous cycle's product development orientation. For Wills and his co-authors, the virtuous cycle was an ideal development pathway for health and medical research generally and, by default, a prescription for industry 
development policy and incentives in these broad fields. The public policy emphasis on biotechnology came a few years later in Australia when state government Premiers in Australia sequentially tied increasing portions of their technology, health, and industry development dollars onto the international biotechnology bandwagon.

In previous work (cf. Sunderland, 2004, 2008) I observed that contemporary biotechnology is by definition a purposive and formal hybrid of scientific practices with industry: the almost sole purpose of which is to follow the virtuous path set out by Wills in 1998. This purposive hybrid marks a significant point in the history of science's relationship with business and for-profit activity. To date, the relationship has oscillated between varying degrees of collaboration, co-determination, and division between science and industry (cf. Ben-Chaim, 2001; Chen, 1992; Gaudillière, 2001; Leiss, 1994). Ravetz (1971, in Leiss, 1994, p. xi) summarizes the various states of hybridity and distinction using four different conceptions of the relationship between science and industry, including the traditionalist view that science should be free of all associations with the state or industry.

1. The idea of science as a technique important to industry;

2. The idea of industry as a technique (productive apparatus) important to science;

3. The idea of science as a form of knowledge valuable in itself; and

4. The idea of science as a vehicle of liberation from dogmatic attitudes and irrational faith (Ravetz, 1971, in Leiss, 1994, p. xi).

All of these conceptions of science and its relationship or non-relationship with industry and capital are present in the full range of formal and informal discourses and definitions of biotechnology on offer. Official policy definitions, however, do not contain this range of interpretations. Rather, contemporary biotechnology policy requires commercial industry intervention in biotechnology research and development. It is argued that the benefits of biotechnology can only be delivered through the virtuous cycle of product development that derives from science-industry collaboration.

Like the virtuous cycle, biotechnology is defined by movement of knowledge and practices from one context to another: namely from a living being to the laboratory to market and ultimately consumption. Both the virtuous cycle and the product development pipeline metaphors are used extensively in official biotechnology discourse. The product development pipeline metaphor is significant because it constitutes a link between the practices of scientific research in biotechnology and industry contexts of product commercialization and sale. The pipeline metaphor is also significant because, in addition to the relational paths of two way mediation that are established through precinct hybridity, the pipeline metaphor presents a normative, apparently linear channel of mediation for biotechnology's discourse materialities. The product development pipeline 
is an officially sanctioned channel of mediation in biotechnology. The pipeline is foregrounded in biotechnology discourses at the exclusion of other potential pathways of mediation, such as the collaborative not for profit research and development approaches canvassed in the UN Human Development Report. Like any medium, the product development pipeline in biotechnology is only intended to carry certain forms of "content." In this case the acceptable content consists of bio-products (things) that are deemed to be desirable to the "receiving" context of larger multinational companies. Desirable in this context also generally means that they can be sold for profit within the existing price system.

\section{TRACKING THE VIRTUOUS CYCLE: CREATING A CHAIN OF REPRESENTATION ACROSS CONTEXTS}

The findings presented in this article derive from an inductive discourse analysis of a corpus of 72 exemplary texts $(700,000$ words) retrieved from contexts that span the full continuum of biotechnology's virtuous cycle: from idea (laboratory or ecology) to product exchange and consumption (market, body, or ecology transformed) between 2001-2007. The texts are representative of their genres during a period in time when biotechnology was being positioned as the key area of policy development and public investment in science and technology.

At the meta-level, the corpus analysis produced a novel theoretical analysis of the virtuous cycle as a series of processes of mediation: politico-economic shifting and movement of meanings (Silverstone, 1999). The detailed theoretical framework for viewing biotechnology as mediation has been published elsewhere (cf. Sunderland et al., 2009). Within this broader mediation framework, the virtuous cycle of biotechnology research and development is understood as a process of recontextualizing and translating knowledge from one context to another. At each recontextualization the defined benefits of biotechnology, and the agents who are benefited, are represented in different ways. Different contexts bring different permutations of who has agency. The "goods," values, and evaluative orientations in each context also differ. The differences between, for example, what a research scientist says in an in depth interview, and what is presented in a policy text, highlight how different social practices can appear to be pursuing the same values or beliefs, but may be acting out different value sets and propositions in different contexts of practice. It also shows how some agents can be privileged in public discourse and how others are marginalized, used for rhetorical purposes, or excluded entirely.

The biotechnology contexts that are referred to in the corpus include:

- spaces of abstraction prior to biotechnological intervention including, for example, ecosystems and the body;

- scientific research and teaching contexts in universities and schools; 
- laboratories in public and private research units;

- computing machines and networks;

- commercialization, product development, and marketing contexts;

- the market of exchange;

- public contexts, including the supermarket, the street, the hospital, the clinic, and the workplace;

- pharmaceutical companies;

- "The Bioindustries";

- the Media;

- industry-research "clusters", "networks", and "hubs";

- "developing" countries and "The Third World";

- "global science and technology";

- stock markets and finance;

- agricultural production contexts;

- government policy and regulatory contexts (ethics is usually included in regulation);

- ecosystems and individual living organisms that have been or will be transformed through biotechnological intervention; and

- economies that will be transformed through the development of bioindustries.

The discussion presented in this article begins with a summary of the primary people, practices, or things that are presented as having agency in biotechnology's virtuous cycle across the contexts outlined above. I use van Leeuwen's (1996, pp. 43-44) conceptions of active and passive agency for these purposes. In his words,

... representations can endow social actors with either active or passive roles. Activation occurs when social actors are represented as the active, dynamic forces in an activity, passivation when they are represented as "undergoing" the activity or as being "at the receiving end of it."

Observations regarding moral agency are derived from a systematic functional grammatical analysis of who and what is portrayed as the grammatical subject or actor who does something (verb) in particular biotechnology texts and in the larger corpus of biotechnology texts.

\section{ACTIVE AND PASSIVE AGENCY IN THE VIRTUOUS CYCLE: WHO IS REPRESENTED MOST OFTEN, WHERE, AND DOING WHAT}

I identify the most frequently named agents who have active agency in the corpus as well as those who have passive (representation only) agency in Table 1. 
VIRTUOUS OR VICIOUS? / 387

\section{Agent 1: Biotechnology}

The non-human "biotechnology" is frequently portrayed as an active agent in the corpus. Biotechnology is portrayed as the agent that is primarily concerned with prophetic and broad future social outcomes; for example, "better lives." These benefits are predominantly described in a future tense and potential space (e.g., "biotechnology promises to be the next great revolution"). The non-human biotechnology is prophetic and transcendent in much the same way that a savior or deity may "promise," "provide," or "allow." Policy makers' use of the agent biotechnology is interesting because it adds to the rhetorical weighting to the apparent inevitability of biotechnology for citizens; for example, "biotechnology offers us." In this case, humans are not portrayed as moral agents but are passive receivers of what biotechnology has to offer us. Accountability for developments in biotechnology is also thus reduced by offering the nominal agent category "biotechnology" rather than functional agent classifications such as the "government," "scientists," or "farmers."

\section{Agent 2: Scientists}

The functional agent classification "scientists" is used frequently in corpus texts. The construction of scientists in the corpus is notable. The written elements of biotechnology texts portray scientists as being involved in the first step of the virtuous cycle (i.e., in discovering, investigating, working, determining, and using). References to scientists are often collocated in the corpus with short sections of scientific and technical language use. For example:

X-ray crystallography begins with a process of carefully growing crystals of purified protein. By firing an x-ray beam through the protein crystal, scientists can determine the molecule's diffraction pattern responsible for causing disease (Abbott Laboratories information brochure on research activities, online resource, $\mathrm{nd}, \mathrm{np})$.

Although scientists are presented in written parts of the corpus texts as having agency only in laboratory contexts, their photos are presented in relation to all contexts represented in the virtuous cycle. This infers that they are at least passive agents in all phases of the virtuous cycle. This pictorial representation of scientists in all contexts connotes a scientific methodology and credibility across the entire virtuous cycle despite the fact that scientists are only active agents in relation to their laboratory work. It also implies that scientists are a priori involved in and supportive of all developments in the virtuous cycle. Yet, through the interviews I conducted with scientists and industry CEOs, I found that bench scientists were among the most conservative and cautious in their views about the potential of biotechnology and the pace at which it should be developed via a commercial product development pathway. While some were involved in spin off companies or other commercial ventures, their ways of representing biotechnology were 
Table 1.

\begin{tabular}{|c|c|}
\hline Agent/Subject & Sentence examples \\
\hline $\begin{array}{l}\text { Biotechnology/ } \\
\text { innovation }\end{array}$ & $\begin{array}{l}\text { - "Life sciences and biotechnology hold the promise of } \\
\text { meeting some of the fundamental needs for food and health } \\
\text { facing the developing world." } \\
\text { - "Biotechnology is also improving food productivity." } \\
\text { - "Globally, innovation is recognized as a key driver of } \\
\text { economic growth." }\end{array}$ \\
\hline Scientists & $\begin{array}{l}\text { - "Our scientists work to ... " } \\
\text { - ". . . scientists are driven by technology and what they can } \\
\text { do with it." } \\
\text { - ". . . scientists can determine the molecule's diffraction } \\
\text { pattern responsible for causing disease." } \\
\text { - "Scientists are now using gene therapy to attack these } \\
\text { diseases. ..." } \\
\text { - "Scientists are investigating genes that will increase the } \\
\text { production of natural fish growth factors. ..." }\end{array}$ \\
\hline Companies & $\begin{array}{l}\text { - "Companies are helping to apply market derived } \\
\text { technologies to crops. ..." } \\
\text { - ". . . Such a gain will most likely occur with a startup } \\
\text { company that is growing and developing valuable } \\
\text { intellectual property." } \\
\text { - "BioBUSINESS-If NSW is to become a leader in the } \\
\text { emerging global biotechnology industry, it must be able to } \\
\text { develop and successfully market its research outcomes by } \\
\text { connecting with globally active enterprises." }\end{array}$ \\
\hline Farmers & $\begin{array}{l}\text { - "Biotechnology has many applications in medicine and care } \\
\text { of the environment, and it's use in agriculture and food } \\
\text { production is well established." } \\
\text { - "Farmers have been using the power of biotechnology for } \\
\text { hundreds of years, even though the underlying genetics } \\
\text { were not fully known." } \\
\text { - "Farmers in the USA growing genetically modified crops } \\
\text { have maintained yields while using fewer chemicals and } \\
\text { reducing costs. ..." } \\
\text { "Plant biotechnology is helping them grow more food and } \\
\text { crops while protecting their land. And it will help them } \\
\text { grow even better food and crops in the future. No wonder } \\
\text { that global plantings of biotech crops increased nearly } \\
20 \text { percent last year." } \\
\text { - "Organic farmers reject technologies that other farmers } \\
\text { incorporate in their croplands. ..." }\end{array}$ \\
\hline
\end{tabular}


VIRTUOUS OR VICIOUS? / 389

Table 1. (Cont'd.)

\begin{tabular}{|c|c|}
\hline Agent/Subject & Sentence examples \\
\hline Governments & $\begin{array}{l}\text { - "To encourage effective networks, the Tasmanian } \\
\text { government, in partnership with relevant stakeholders, } \\
\text { will. ..." } \\
\text { - "The Government believes that the strategy marks a significant } \\
\text { step in harnessing the collective talent, energy, and resources } \\
\text { of all those dedicated to securing Australia's economic } \\
\text { future. ..." } \\
\text { - . . the NSW biotechnology sector will be encouraged and } \\
\text { supported to take a proactive role in forging Australia's } \\
\text { position. ..." } \\
\text { "There may be government assistance given to } \\
\text { programmes to help to send our people to work } \\
\text { overseas. ..." }\end{array}$ \\
\hline $\begin{array}{l}\text { Anti-biotech } \\
\text { activists }\end{array}$ & $\begin{array}{l}\text { - "Anti-biotech activists argue against western style } \\
\text { capitalism. ..." } \\
\text { - "The anti-biotech activists incorrectly suggest that. . .." } \\
\text { - ". . . anti-biotech activists oppose genetic patents. . ." } \\
\text { - ". . . the company apparently feared a food scare } \\
\text { generated by activists. ..." } \\
\text { - "If anti-biotech activists really are concerned about gene } \\
\text { flow." }\end{array}$ \\
\hline $\begin{array}{l}\text { The } \\
\text { community, } \\
\text { public, and } \\
\text { citizens }\end{array}$ & $\begin{array}{l}\text { "The Tasmanian community generally must obtain } \\
\text { direct benefits from the advances in and diffusion of } \\
\text { science and technology in a range of areas, such as } \\
\text { medical science and technology and information } \\
\text { technology." } \\
\text { " "Specific initiatives proposed in the Commission's White } \\
\text { Paper on European Governance are particularly relevant for } \\
\text { enhancing public confidence...." }\end{array}$ \\
\hline $\begin{array}{l}\text { Developing } \\
\text { countries and } \\
\text { the third world }\end{array}$ & $\begin{array}{l}\text { - ". . . researchers and companies will offer crops that } \\
\text { appeal to farmers in developing countries." } \\
\text { "If you care about developing countries you should take } \\
\text { note of the fact that the most eminent plant breeders in } \\
\text { those countries want to have access to modern biotech- } \\
\text { nology to breed more productive and more nutritious } \\
\text { crops." } \\
\text { " Europe should contribute to technical assistance, } \\
\text { capacity-building and technology transfer to allow } \\
\text { developing countries to participate in negotiating and } \\
\text { implementing international agreements and } \\
\text { standards. ..." }\end{array}$ \\
\hline
\end{tabular}


vastly different to other groups along the product development pathway. Scientists' ways of representing themselves and biotechnology in general were particularly different from policy writers, company CEOs, and even their bosses (science bureaucrats and directors of research institutes) who are involved in raising funds for research and liaising with governments and public relations. It seems that it is not scientists but rather the people who surround them that are responsible for creating hyperbolic and prophetic visions of what biotechnology as an agent will provide for entire industries, countries, and humanity. Interestingly, neither science bureaucrats nor policy makers are named in the thesis corpus as agents even though their influence can be felt in numerous ways.

\section{Agent 3: Companies}

In the corpus companies are primarily presented as passive agents to be partnered with by universities or governments. Companies are presented as a vital middle component of the virtuous cycle of biotechnology but, like scientists, farmers, community, and developing countries, they are afforded no specific active agency in official biotechnology discourses. For example:

BioBUSINESS-If NSW is to become a leader in the emerging global biotechnology industry, it must be able to develop and successfully market its research outcomes by connecting with globally active enterprises.

In the virtuous cycle, companies constitute an instrumental "black box" of activity. They are generally presented in contexts and processes of conversion (i.e., the almost invisible and possibly most taken for granted section of the virtuous cycle where research is apparently literally turned into profit, products, widespread benefit, etc.). In many cases companies are convergent with laboratory and research contexts, especially in the case of start up companies or multinational companies that have dedicated R\&D laboratories.

\section{Agent 4: Farmers}

Farmers are presented in limited contexts associated with growing genetically modified crops or, in some aberrant texts, in rejecting genetically modified crops. They are presented alternately as important participants in the virtuous cycle by helping to produce better and more environmentally friendly foods and also as beneficiaries of the virtuous cycle as consumers of genetically modified seed and new herbicides and pesticides that accompany new genetically modified plants. Farmers' roles and attitudes toward biotechnology have been significant in the politics of debate between anti-biotechnology activists and pro-biotechnology spokespeople. Their inclusion as agents is a passive one but they are nevertheless attributed with significant veto power in relation to delivering genetically modified foods to consumers. The most frequent references to farmers occur not in 
policy documents but in mass media representations, particularly those that feature a strong "for" or "against" position on genetically modified foods.

\section{Agent 5: Governments}

Governments are presented as being variously responsible for developing and regulating the emerging bioindustries for the benefit of the public and their country's future. Like the representation of biotechnology's agency discussed above, governments are presented as being responsible for creating a virtuous and prosperous biotech-mediated future. So, at least in this way, biotechnology is working at one with governments. For example,

Bio 21 is a key part of the Victorian Government's drive to make Victoria the smart society, generating prosperity and well-paid jobs for Victorians and Australians (Victorian Government, 2000).

Governments are responsible for both promoting industry developments along the lines of a virtuous cycle of product development and restraining its development through regulation. Accordingly, there are a lot of mentions of ethics, regulation, risk assessment, and safety in government documents that outline their public role and approach to biotechnology. As I will discuss more below, the safety and risk discourse of responsibility is dominant in relation to government's role in biotechnology. This does not cater though for agents or persons who are silenced or marginalized in biotechnology discourse or who are rendered as objects in relation to the technology. This group of objectified persons includes for example people with disabilities or chronic disease conditions that can be attributed to genetic inheritance.

\section{Agent 6: Anti-Biotech Activists}

Anti-biotech activists are predominantly presented in relation to contexts of food production and consumption and protest. Negative representations of people who oppose biotechnology developments are most evident in mass media and internet texts. For example:

Anti-biotechnology activists argue against Western-style capitalism and for boutique markets that sell organically grown, biotech-free foods. But their arguments are not relevant to the issue of meeting human needs or developing a sustainable and diverse ecology. Companies that play into activist hands delay expansion of technology that can solve many problems (Prakash, 2000, np).

These negative representations are not common in official policy texts but they do also appear in a more subtle form in public education documents produced by some governments. In education documents, people who raise questions or object to biotechnology development are referred to using more moderate terms 
such as "some people," "environmentalists," or "activists." Portrayals of this group in biotechnology discourse employ extensive strategies for invoking and inscribing judgment and appreciation. The processes that the "anti-biotechnology community" are portrayed as engaging in are also heavily modalized through the use of terms like "argue," "believe," "suggest," "fear," and "oppose." Other terms used to describe this group include "opponents," "activists," "environmental groups," "critics," and "anti-biotechnologists." All of these categories imply that the persons positioned within them display uniformly negative and in most cases apparently ill informed orientations toward biotechnology. This group is represented in the corpus as having agency (i.e., in doing things that have an impact but they are not "given voice" or authorship of particular ways of representing). Anti-biotech activists are often presented as preventing or being opposed to the inherently virtuous outcomes of biotechnology, particularly in relation to producing genetically modified foods for poor countries. For example,

The apparent willingness of biotechnology's opponents to sacrifice people for their cause disturbs scientists who are trying to help the world's poor (Bailey, 2001, np).

Such representation simultaneously reaffirms the supposed virtue of applying biotechnology in contexts of consumption and contributes to overriding negative representations of people who oppose developments in biotechnology.

\section{Agent 7: The Community, the Public, and Citizens}

The community and citizens are represented in the final context or step of the virtuous cycle: contexts of production and consumption. Citizens and community's role is primarily to benefit from advances in biotechnology science and to consume the products that result from the virtuous cycle of product development. The representation of agency for citizens in policy documents is particularly interesting. Biotechnology policy documents analyzed in the corpus almost uniformly include references to community benefits and citizens in the introduction and conclusion to the document. Yet, the substantive components of the policy documents that outline actual strategies and funding priorities do not include any reference to community or citizens at all. As agents "the community" and "citizens" are not included as a benefactor in the contexts where this kind of commercial "value" is created from public investment in biotechnology science.

... Biotechnology is likely to bring substantial benefits to communities and economies in rural and regional NSW, particularly in agribusiness, and to create associated opportunities for the biotechnology industry. However 
there is a need to minimise the potential for negative effects (for example, on the viability of small farms) and ensure equity of access for remote communities to new technologies (NSW Government, 2001).

While the "community" is often presented in contexts of assumed or future benefit in the corpus as above, the "public" is associated with debate regarding biotechnology developments, in particular genetically modified foods. My comparison of international policy documents also reveals that the emphasis on community acceptance and support for biotechnology in European Union and United Nations documents is much greater and more in depth than policy documents from individual countries. This is partly due to their supranational and humanitarian functions, but also due to differences in government orientations and discourse on biotechnology between European and other developed countries including the United States, Ireland, and Australia. It is noticeable that European countries such as Sweden and Norway and also New Zealand foreground discussion about community acceptance in a more respectful and sustained way than their Australian and U.S. counterparts. In all cases though the community is presented as a predominantly passive agent in official biotechnology discourse and has no voice or authorship of its own.

\section{Agent 8: Developing Countries and the Third World}

Developing countries are one of the most highly referred to subject groups in the corpus yet they hold the least amount of inferred agency of any group presented. Many people speak for developing countries in this corpus but we do not hear much from developing countries themselves. For example,

The developing world is demanding effective and affordable treatments and vaccines for diseases that not only impact on the lives of individuals, but significantly constrain economic growth and development opportunities. Biotechnology offers great prospects for vaccines against diseases such as HIV/AIDS, which infects 16,000 new people in the developing world every day, and malaria which infects up to half a billion people each year (Victorian Government, 2002).

This pattern can partly be explained by two things. First, many governments and science bureaucrats portray genetically modified crops as a solution to food shortages and unproductive agricultural contexts. This application of genetic technology is an official and virtuous rationale for why we should invest in genetic research. It is also a basic fact that most experiences of food shortages, preventable diseases such as HIV and malaria, and agricultural problems are experienced in "developing nations." The second reason for the high level of representation but low level of grammatical agency is that relatively few of the world's "developing" countries have biotechnology policies or strategies. When they do have policies, 
these are often quite different in function and purpose to other countries. ${ }^{1}$ Because of the above two dynamics, people from developing countries are primarily portrayed in contexts of primitive agriculture, disease, and poverty in relation to biotechnology. This is created via both written and pictorial representations.

\section{SOCIAL AND ETHICAL ASPECTS OF AGENCY IN THE VIRTUOUS CYCLE}

There are several significant and broad implications of the forms of agency and contextual representation highlighted above. While there is not sufficient space to launch a full discussion of each implication here, I will summarize the main points below in anticipation that they will produce future discussion and embellishment.

\section{Biotechnology and the Human Condition}

The fact that biotechnology is presented as an agent that is responsible for broad scale social and economic benefit in the corpus is highly significant but not new. The construction of biotechnology as an active agent taps into the historically salient view that technological advancement as the primary source of advancing the human condition or, if you like, "the good life" (cf. Croteau \& Hoynes, 2003; Innis, 1949; Noble, 1984). As Winner (2004, p. 104) observes, "[i]n the twentieth century it is usually taken for granted that the only reliable source for improving the human condition stems from new machines, techniques, and chemicals." The examples of where biotechnology is presented as an active agent, and in what contexts, are all consistent with this broader technological determinist paradigm. This has implications for our conceptions both of what constitutes the good (ethical) life and how it can be achieved. At present, and in the immediate past present, we have been told that the future bio-mediated utopia is to be reached via engagement in the virtuous cycle of product development and consumption. It also presents new technologies, in this case biotechnology, as an inherently moral and worthwhile pursuit to the degree that they will provide humanity with a seemingly concrete pathway to a future space and way of being that is morally good and desirable.

\footnotetext{
${ }^{1}$ As I have explored elsewhere (Sunderland, 2004, pp. 132-139), developing countries and the United Nations often portray biotechnology industry investment as a way of achieving first world or developed world status. This is different to countries such as Australia, Canada, Ireland, or Sweden which portray biotechnology as a way to reach a future context of prosperity, health, and wellbeing for all citizens. For developing countries that do have biotechnology policies, such as South Africa (South Africa Government, 2001), the official utopia they are aiming for is the "developed world." There is much public and academic debate around the role of developing countries in biotechnology industry development so I will not proceed on this topic here apart from saying that it is a major area of ethical concern.
} 
Such privileging of the nominal "biotechnology" as the primary and prophetic agent in this field removes agency from the persons who are responsible for scientific innovation and translating knowledge such as scientists, policy makers, company executives and employees, farmers, retailers, health providers, and so on. Lack of agency for these groups means lack of public scrutiny, awareness, and lack of true knowledge and understanding by non-scientific members of the public. It also means that the persons who are actually involved in creating the complex web of practices we refer to as biotechnology are largely disregarded as moral agents in the virtuous cycle at a time when we really need them to be present, accountable, and vociferous. In the agency game, I think we are all falling folly to policy makers and select others' tendencies to create over-inflated and ultimately nullifying constructions of science and its apparently omniscient role in human society and progress.

\section{Spaces of Moral Engagement and Ethical Response}

While biotechnology is awarded the ultimate prize of moral agency in official biotechnology discourse, there are two primary spaces outlined for moral engagement and response: the market and government. The dominant of these two spaces is the market of exchange. The consumer is portrayed as the primary functional agent group that is involved in moral and ethical deliberation and decision making. Citizens are attributed agency primarily through their roles as consumers. The primary medium and criteria for deliberative moral action is, apparently, consumer demand for bio-products in an open consumer market. There are several implications of portraying the market as the ultimate moral medium in the virtuous cycle. First, the market of exchange is the final or perhaps penultimate context portrayed in the virtuous cycle if one maintains the view that the cycle is linear. Hence, the most influential "moral deliberation" does not occur until the virtuous cycle is almost complete. This means that there is little deliberate transparency in the process of mediation up until the point of commercial exchange - apart from government regulation which I will discuss below. Second, market morality operates on two principles: demand and supply. Policy makers and other industry bodies who assume that citizens will have their say in the market assume that all citizens have equal political and physical access to the market and equal buying or veto power which is not the case either between households in a given economy or between countries. Third, both demand and supply are manipulated by various agents in various contexts involved in or alongside the official virtuous cycle mediation pathway. This means that the market does not operate in a condition of full disclosure, informed consent, or equal access and decision making power thereby effectively crippling its capacity to function for ultimately good or moral outcomes. At best, the market is a political battleground where various parties can lobby their case and attempt to sway the masses. 
Other than the market, the only moderating force on the virtuous cycle portrayed in the corpus is government. Ethics and regulation are frequently mentioned in government documents concerning biotechnology but it is a very particular discourse on/way of seeing ethics that is inscribed. As Fraser (2001, np) argues, the dominant tendency in both ethics and public consultation is "to simplify and reduce the variety and complexity of arguments to those that sit comfortably alongside scientific risk analysis." In the Victorian Strategic Plan for biotechnology, for example, every reference to ethics is in collocate with the terms regulation; committee; advisory; and/or safety. The consistency with which ethics is represented/collocated in this way in policy documents relating to biotechnology suggests that is not just a tendency or coincidence but that the code/regulatory approach to ethics is in fact a generic feature of biotechnology policy and practice more generally. This is confirmed by the fact that the code and regulation approach to ethics is consistent across government departments dealing with biotechnology research and development in Australia and abroad. Despite this codified approach to scientific risk in lieu of ethics, there are significant problems with the way scientists are incorporated into decision making processes in relation to biotechnology and likely many other areas of high profile and potentially high profit science.

\section{Instrumentalization and Passivation of Key Expert Groups}

Key agents in the virtuous cycle are instrumentalized and passivated in official biotechnology discourse to the detriment of the biotechnology industry and society. Instrumental agents include most notably scientists, companies, and farmers. In short, governments, policy makers, and strategic communicators assume a lot. Policies for biotechnology industry development have routinely presented scientists as being present and active along the entire continuum of the virtuous cycle via pictorial and other representations, yet scientists are not present and active. Indeed, my interviews and the accompanying corpus of texts from media, policy, industry, peak bodies, and consumer groups indicate that bench scientists apparently don't have much to do with biotechnology mediation at all once it is translated out of their labs in the form of products, processes, tools, techniques, or published knowledge. Yet, in the interviews I conducted with local scientists, bench scientists are among the most conservative in their views on how quickly biotechnological research should be translated into other contexts along the product development pipeline and the degree they should be subjected to public and expert scrutiny via the traditions of scientific rigor and method. It is not your average bench scientist who claims that biotechnology is going to save the world: it's their research boss or their local politician (in my experience it's becoming increasingly difficult to tell these groups apart). 
Likewise, the role of companies in the virtuous cycle is almost entirely assumed. There is a period of closeness between research and industry contexts when small companies are spun off from research institutes and this is logical because it is typically the same people who invented the idea who start the company. Yet apart from this example of the spin off company, there is little in official biotechnology discourse that actually attends to the "voice," intentions, or moral agency of companies themselves. As indicated above, companies are presented as a black box of activity that more or less miraculously results in knowledge being transformed into products for sale and ultimately profit. Once again, the actual processes of mediation that occur are invisible and apparently beyond public or scientific involvement. The missing link in representations of the virtuous cycle is an account of how company mediated products and profits actually deliver the better life we are told about. How do governments recoup on their investment? Where is the scientific community at this point? Do companies want to work with universities in the virtuous cycle in the way that government requires?

Finally, as indicated above, farmers have suffered the same fate as scientists and companies in that they are integral in the virtuous cycle but are rarely given a voice in official discourse. In the context of genetically modified foods and crops, farmers are perhaps the closest group to consumers both in a proximal and perhaps a social sense (i.e., the most like the consumer). But, unlike any other group in the corpus, farmers are presented as having something to lose from the trajectory of the virtuous cycle. The time it takes to plant and grow crops is lengthy and one choice of crop or seed typically precludes others. Farmers are also at ground zero when it comes to the potential or perceived environmental impacts of genetically modified plants and animals. In this sense at least, farmers truly are the final barrier between all of the other contexts on the virtuous cycle and the environment and the public. So why are they presented only as passive and instrumental agents by decision makers in biotechnology? The war over the fate of the farmers has predominantly been held in the popular media and has included some of the most vitriolic and one-handed treatments of the issues and players in the debate. Those farmers who have made public comments have been subjected to the same scrutiny and even threats that "anti-biotechnologists" have.

The treatment of farmers, scientists, and others who speak out against the trajectory or substance of the product development flow indicates that although the product development cycle is heralded as virtuous, there is much that goes on within its walls that should be named the opposite. I argue that we need to hear from and respond to the people who deal with the realities of science and product development, evaluation, commercialisation, and use if we are to maintain any level of virtuousness. If we are to truly reap the benefits of important scientific advances, the virtuous cycle should not be contained or directed by only those who hype it into existence at the textual level. 


\section{CONCLUSION}

I see the virtuous cycle as an ocean of activity rather than a controlled or controllable product pipeline. Once organic material, information, and knowledge is out of the body, out of the laboratory, there is no real concrete pipe that will sustain or contain that information in a linear trajectory. Rather, the materials of biotechnology move in multiple and varied ways across both official and unofficial contexts and pathways of development and use. In this article I have sought to identify the human and non-human agents that are welcomed in accessing and determining the benefits of contemporary biotechnology research and commercialization in official pathways of development. There is still much to do in identifying and analyzing unofficial and unexpected pathways. By analyzing active agency and passive representation in a corpus of exemplary international texts, I have identified that the spaces for true active agency and ethical responsiveness in the virtuous cycle are very limited. It is particularly interesting that key agency groups such as scientists, companies, and farmers are not ascribed with active agency, but are rather used as rhetorical figures to enhance credibility and perceptions of efficient and effective knowledge translation along a product development pathway. While this article has sought to identify those that are recognized in biotechnology discourse, future research and writing should pay critical attention to the human and non-human agents who are not ascribed with agency or even personhood in the virtuous cycle. Examples would include people conceived through reproductive technologies and genetic screening, people with inherited disabilities, and the non-human animal world.

\section{ACKNOWLEDGMENTS}

The author would like to acknowledge Jayne Clapton, Elizabeth Kendall, and Anne-Marie Tripp of Griffith University for their contributions to this article in the form of conceptual feedback and critique and editorial suggestions.

\section{REFERENCES}

Bailey, R. (2001, January 2). Dr. Strangelunch — Or: Why we should learn to stop worrying and love genetically modified food. Reason Magazine, January 2.

Ben-Chaim, M. (2001). The scientific discovery of "Natural Capital": The production of catalytic antibodies. Studies in History and Philosophy of Biological and Biomedical Sciences, 32(3), 413-433.

Chen, W. (1992). The laboratory as business: Sir Almroth Wright's vaccine program and the construction of penicillin. In A. Cunningham \& P. Wiliams (Eds.), The laboratory revolution in medicine (pp. 245-292). Cambridge: Cambridge University Press.

Commonwealth of Australia. (1999). Australian Health and Medical Research Strategic Review The virtuous cycle, working together for health and medical research (pp. 299-333). Canberra: Department of Health and Aged Care. 
Croteau, D., \& Hoynes, W. (2003) Media studies: Industries, images and Audiences (3rd ed.). Thousand Oaks, CA: Pine Forge Press.

Fraser, V. (2001). Enhancement agri-culture: Whose utopia? Whose story? QUT Applied Ethics Seminar Series 2001. Available on-line at: ||Beaker|www $\backslash$ hhs $\backslash$ researchcentreslethics $\backslash$ Fraserseminar01.htm, Date accessed 1/11/02.

Gaudillière, J. P. (2001). The pharmaceutical industry in the biotechnology century: Toward a history of science, technology, and business. Studies in History and Philosophy of Biological and Biomedical Sciences, 32(1), 191-201.

Innis, H. A. (1949). The bias of communication. The Canadian Journal of Economics and Political Science / Revue canadienne d'Economique et de Science politique, 15(4), 457-476.

Leiss, W. (1994). The domination of nature. New York: Beacon.

New South Wales (NSW) Government. (2001). Biofirst: NSW biotechnology strategy. Sydney, NSW: NSW Government.

Noble, D. F. (1984). Forces of production: A social history of industrial automation. New York: Oxford University Press.

Prakash, C. S. (2000). Can genetically engineered crops feed a hungry world? YES-We must tap biotech's potential. San Francisco Chronicle, Thursday, March 30,2000 .

Silverstone, R. (1999). Why study the media? Thousand Oaks, CA: Sage Publications.

South Africa Government. (2001). A national biotechnology strategy for South Africa. South African Government.

Sunderland, N. (2004). Biotechnology as media: A critical study of the movement of meanings associated with contemporary biotechnology. Doctoral thesis available online at Australian Theses Online.

Sunderland, N. (2009). Biotechnology, society, and ecology. In N. Sunderland, P. Graham, P. Isaacs, \& B. McKenna (Eds.), Towards humane technologies: Biotechnology, new media and ethics. Taiwan, Taipei: Sense Publishers.

Sunderland, N., Graham, P., Isaacs, P. \& McKenna, B. (Eds.). (2009). Towards humane technologies: Biotechnology, new media and ethics. Taiwan, Taipei: Sense Publishers.

Trujillo, A. (2002). Mexico speech delivered by CEO and President, Recall Corporation. Available online at: http://www.recall.com/english/news_white.asp

United Nations. (2001). Human development report 2001. United Nations.

U. S. Council of Governmental Relations. (1999). The Bayh-Dole Act: A guide to the law and implementing regulations. Accessed online June 7, 2009, at: www.cogr.edu. docs.Bayh-Dole.pdp

van Leeuwen, T. (1996). The representation of social actors. In C. Rosa Caldas-Coulthard \& M. Coulthard (Eds.), Texts and practices-Readings in critical discourse analysis, Routledge, London.

Victorian Government. (2000). Bio21: Capturing the opportunity. Melbourne, VIC: Victorian Government.

Victorian Government. (2002). Biotechnology strategic development plan for Victoria. Melbourne, VIC: Victorian Government.

Winner, L. (1994). Technologies as forms of life. In D. M. Kaplan (Ed.), (2004). Readings in the philosophy of technology (pp. 103-114). Lanham, MD: Rowman and Littlefield. 
400 / SUNDERLAND

\section{Other Articles On Communication By This Author}

Davis, G., \& Sunderland, N. A. (2000). A federation amid global imperatives: Implications for participation in the policy process. In C. Sampford \& T. Round (Eds.), Beyond the republic: Meeting the global challenges to constitutionalism. Sydney, NSW: Federation Press.

Sunderland, N. (2000, November). How we propagate the everyday: Discourse and social practice in higher education. New Horizons in Education: Journal of the World Education Foundation.

Sunderland, N., Graham, P., Isaacs, P., \& McKenna, B. (2009). Towards Humane Technologies: Biotechnology, new media and ethics. Taiwan: Taipei: Sense Publishers.

Sunderland, N., Catalano, T., \& Kendall, E. (2009, October). Missing discourses: Concepts of joy and happiness in disability. Disability and Society, 24(6).

Direct reprint requests to:

Naomi Sunderland

Griffith University, Logan Campus

Meadowbrook, QLD 4131

Australia

e-mail: n.sunderland@griffith.edu.au 